Maurer School of Law: Indiana University

Digital Repository@Maurer Law

Indiana Law Journal

Volume 16 | Issue 6

Article 7

\title{
8-1941
}

\section{Privileged Communications}

Follow this and additional works at: https://www.repository.law.indiana.edu/ilj

Part of the Evidence Commons

\section{Recommended Citation}

(1941) "Privileged Communications," Indiana Law Journal: Vol. 16 : Iss. 6 , Article 7.

Available at: https://www.repository.law.indiana.edu/ilj/vol16/iss6/7

This Note is brought to you for free and open access by the Law School Journals at Digital Repository @ Maurer Law. It has been accepted for inclusion in Indiana Law Journal by an authorized editor of Digital Repository @ Maurer Law. For more information, please contact rvaughan@indiana.edu.

\section{$\Psi$}

JEROME HALL LAW LIBRARY

INDIANA UNIVERSITY

Maurer School of Law
Bloomington 


\section{EVIDENCE \\ PRIVILEGED COMMUNICATIONS}

The New York City council appointed a committee to investigate charges of negligence and maladministration at the city-controlled Lincoln Hospital. At the committee hearing, the hospital medical superintendent withheld confidential case record information on the grounds that the New York Civil Practices act prohibited a physician from disclosing any information acquired in attending a patient. Held, the statutory privilege included examination before legislative committees. New York City Council v. Goldwater, 31 N. E. (2d) 31. (N. Y. 1940).

At common law, patient-physician communications were not privileged from disclosure in judicial proceedings. However, statutes have changed the rule in the majority of the states. 8 WIGMORE, EVIDENCE (3d ed. 1939) \& 2380. In the principal case the court by a liberal interpretation applied the privilege to non-judicial proceedings. It felt the decision was necessary to carry out the policy of the statute. Buffalo Loan, Trust \& Safe-Deposit Co. v. Knights of Templar \& Masonic Mutual Aid Ass'n, 126 N. Y. 450, 454, 27 N. E. 942, 943 (1891). Section 354 of the Civil Practices Act indicates that the privilege applies to any examination of a physician as a witness. This was strengthened by dicta in a previous New York case to the effect that witnesses before the commissioner of accounts were entitled to all the privileges and protection extended by law to witnesses in judicial proceedings. Matter of Herschfield v. Hanley, 228 N. Y. 346, 127 N. E. 252 (1920).

A dissent advocated restricting the statute to its "primary purpose." Buffalo Loan, Trust and Safe-Deposit Co. v. Knights Templar and

24 Board of County Comm'rs. v. Lafayette, M. and B. Ry. Co., 50 Ind.

85 (1875) ; Mercantile Comm. Bank v. So. Eastern Ind. Coal Corp.,

93 Ind. App. 313, 169 N. E. 91, 171 N. E. 310 (1929); Wright

v. Hughes, 119 Ind. 324,21 N. E. 907 (1889).

25 Compare statutes cited supra note 19.

28 The drafters of the Uniform Business Corp. Act expect this position to be taken by the courts. 9 UNIFORM LAWS ANN. (Perm. ed. 1932) 58.

${ }^{27}$ Columbian Athletic Club v. State, 143 Ind. 98, 40 N. E. 914 (1895). 
MIasonic Mut. Aid Ass'n, 126 N. Y. 450, 454, 27 N. E. 942, 943 (1891). But see Atchinson, T. and S. F. R. Co. va Reesman, 60 F. 370,373 (1894). Without the ability to find the facts, legislative investigations are of little help in preparing intelligent statutes. The privilege shields from inquiry the very abuse concerning which the public is entitled to full information. See People ex rel Wood v. Lacombe, 99 N. Y. 43, 49, 1 N. E. 599, 600 (1855); City Bank F. T. Co. v. N .Y. C. R. R. Co., 253 N. Y. $49,57,170$ N. E. 489,492 (1930). 